\title{
MENGKAJI PENGARUH ASPEK KONDISI SOSIAL DAN EKONOMI TERHADAP MINAT ANAK KELUARGA NELAYAN UNTUK MELANJUTKAN PENDIDIKAN KE PERGURUAN TINGGI
}

\author{
Shendy Andrie Wijaya ${ }^{1)}$ Roro Aditya Novi Wardhani ${ }^{2)}$ \\ IKIP PGRI JEMBER \\ shendy.aw@yahoo.com ${ }^{1)}$ dhee251110@gmail.com ${ }^{2)}$
}

\begin{abstract}
One of the problems on the progress of educational level that is still a lot of basic education age children can no longer go on to secondary school level let alone up to the college level. Many factors affect the condition. The main factors that the ordinary is the reason the family is expensive tuition fees for middle school to College, so that parents are more likely to send his son to elementary education only. Most parents sent his son worked after graduating from SD and SMP, whether it be labor or help parents traveling etc. This happens on the fishing communities in the village a reality Puger Kulon, still many fishermen did not continue her studies up to College. This research is explanatory research classified as research i.e. research to examine relationships between variables that influence or hypothesized. A form of statistical analysis used was Multiple Linear Regression Models. The results of this research show that there are partial and simultaneous influence aspects of social and economic conditions against the interest of the child the family fishermen to continue their education into college. This is shown by the value standard of sig 0,00<0,05. The conclusion from this study is there is influence aspects of social and economic conditions against the interest of the child the family fishermen to continue their education into College in district Puger Puger Jember Regency of Kulon Village.
\end{abstract}

Keywords: Social Economic Conditionsl, Interests

\begin{abstract}
Abstrak
Salah satu masalah pada kemajuan tingkat pendidikan yang masih banyak usia pendidikan dasar anak tidak bisa lagi melanjutkan ke tingkat sekolah menengah apalagi sampai ke tingkat perguruan tinggi. Banyak faktor yang mempengaruhi kondisi tersebut. Faktor utama yang biasa adalah alasan keluarga adalah biaya kuliah yang mahal untuk sekolah menengah ke perguruan tinggi, sehingga orang tua lebih cenderung untuk mengirim anaknya ke pendidikan dasar saja. Kebanyakan orang tua mengirim anaknya bekerja setelah lulus dari SD dan SMP, entah itu tenaga kerja atau membantu orang tua traveling dll. Hal ini terjadi pada masyarakat nelayan di desa kenyataan Puger Kulon, masih banyak nelayan yang tidak melanjutkan studinya ke perguruan tinggi. Penelitian ini merupakan penelitian explanatory yang digolongkan sebagai penelitian yaitu penelitian untuk menguji hubungan antara variabel yang mempengaruhi atau dihipotesiskan. Suatu bentuk analisis statistik yang digunakan adalah Multiple Regression Regression Regression. Hasil penelitian ini menunjukkan bahwa terdapat aspek pengaruh parsial dan simultan terhadap kondisi sosial dan ekonomi terhadap kepentingan anak nelayan keluarga untuk melanjutkan pendidikan ke perguruan tinggi. Hal ini ditunjukkan dengan nilai standar sig $0,00<0,05$. Kesimpulan dari penelitian ini adalah ada pengaruh aspek kondisi sosial dan ekonomi terhadap kepentingan anak nelayan keluarga untuk melanjutkan pendidikannya ke Perguruan Tinggi di Kabupaten Puger Puger Jember Kabupaten Kulon.
\end{abstract}

Kata Kunci: Kondisi Sosial Ekonomi, Minat 


\section{PENDAHULUAN}

Seiring dengan perkembangan zaman, peranan perguruan tinggi menjadi sangat penting untuk menyiapkan peserta didik menjadi anggota keluarga yang memiliki kemampuan akademik dan professional yang dapat menerapkan, mengembangkan, dan atau menciptakan ilmu pengetahuan teknologi dan kesenian. Untuk menginjak ke perguruan tinggi, sebelumnya harus sudah menyelesaikan pendidikan menengah yakni pada SMA. Fenomena yang terjadi, pada setiap tahun ajaran baru sering timbul keresahan orang tua jika anaknya tidak dapat meneruskan sekolahnya atau putus sekolah karena biaya pendidikan yang begitu mahal, apalagi jika memasuki perguruan tinggi. "Bagi rumah tangga yang berpenghasilan rendah tentu akan merasa berat untuk membiayai pendidikan anak-anaknya, apabila meneruskan ke sekolah yang lebih tinggi". (Mulyanto Sumardi dan Hans-Dieter Evers dalam Kurnia Asih, 2006:3). Sedangkan orang tua yang mempunyai penghasilan tinggi, dalam pemenuhan kebutuhan sekolah anak tidak akan merasa keberatan dan kesulitan, berbeda dengan orang tua yang mempunyai penghasilan rendah. Orang tua memegang peranan penting bagi pendidikan anaknya yaitu disamping sebagai pendidik yang utama juga sebagai penyandang dana dalam pemenuhan kebutuhan pendidikan anaknya tersebut.

Harapan masa depan anak dari orang tua pada akhirnya akan menimbulkan masalah bagi orang tua untuk menentukan alternatif pilihan terhadap kelanjutan sekolah bagi anak-anaknya. Minat anak untuk melanjutkan pendidikan ke jenjang yang lebih tinggi akan dipengaruhi oleh beberapa faktor, seperti: cita-cita atau aspirasi, kemampuan belajar, kondisi anak (kondisi fisik dan kondisi psikologis), kondisi lingkungan (lingkungan keluarga, lingkungan sekolah serta lingkungan keluarga). Khairani (2013:139-140) juga menyebutkan bahwa faktor-faktor yang mempengaruhi minat yaitu: 1) Factor inner urge, 2) Factor of social motive, dan 3) Emotional factor.
Menurut Gerungan (2006:4) keadaan sosial ekonomi keluarga tentulah berpengaruh terhadap perkembangan anakanak, apabila kita perhatikan bahwa dengan adanya perekonomian yang cukup, lingkungan material yang dihadapi anak di dalam keluarganya itu lebih luas, ia mendapat kesempatan yang lebih luas untuk mengembangkan bermacam-macam kecakapan yang tidak ia kembangkan apabila tidak ada prasarananya. Dalam penelitian Ajake (2013) juga menyatakan bahwa status sosio-ekonomi keluarga mempengaruhi pendidikan seorang anak. Dengan begitu anak yang berada dalam kondisi ekonomi keluarga yang baik akan terpenuhi semua yang dibutuhkan dalam pendidikannya sehingga dapat menjadikan minat anak tersebut untuk melanjutkan pendidikan ke perguruan tinggi.

Dewasa ini masih banyak dijumpai adanya masalah pada sistem pendidikan di Indonesia. Salah satunya adalah banyak anak usia Pendidikan Dasar tidak lagi dapat melanjutkan ke tingkat Sekolah Menengah apalagi sampai jenjang Perguruan Tinggi. Banyak faktor yang mempengaruhi kondisi tersebut. Faktor utama yang biasa menjadi alasan keluarga adalah mahalnya biaya pendidikan untuk Sekolah Menengah sampai Perguruan Tinggi, sehingga para orang tua lebih cenderung menyekolahkan anaknya sampai pendidikan dasar saja. Faktor lainnya adalah masih kurang perhatiannya orang tua terhadap pentingnya pendidikan bagi anak-anak mereka. Kebanyakan orang tua menyuruh anaknya bekerja setelah tamat dari SD dan SMP, baik itu menjadi buruh atau membantu orang tua melaut dan lain sebagainya. Hal ini yang terjadi pada masyarakat nelayan Puger, yang kenyataannya masih banyak anak nelayan tidak melanjutkan pendidikannya sampai ke Perguruan Tinggi. Timbulnya keadaan tersebut juga tidak lepas dari pendapatan orang tua dan jenis pekerjaan pada lingkungan keluarga tersebut. Hubungan orang tuanya hidup dalam status sosial ekonomi serba cukup dan kurang mengalami tekanan-tekanan fundamental seperti dalam memperoleh nafkah hidupnya 
yang memadai. Orang tuanya dapat mencurahkan perhatian yang lebih mendalam pada pendidikan anak-anaknya apabila ia tidak dibebani dengan masalahmasalah kebutuhan primer kehidupan manusia.

Keluarga nelayan di Kecamatan Puger, menurut data Monografi Kecamatan Puger tahun 2014, wilayah Kecamatan Puger yang terbagi menjadi 12 desa memiliki luas wilayah sekitar 148,99 $\mathrm{Km}^{2}$ dan penduduknya sebesar 114.506 jiwa ini, memiliki masalah yang cukup serius di bidang pendidikan, hal ini tergambar dari jumlah anak Sekolah Dasar sebanyak 8.579 anak, Sekolah Menengah Pertama sebanyak 3.804 anak, dan Sekolah Menengah Atas sebanyak 1.296 anak. Data tersebut menunjukkan minat masyarakat untuk melanjutkan sekolah ke jenjang selanjutnya yang masih rendah. Khusus pada warga Desa Puger Kulon yang masih banyak belum menyelesaikan pendidikan dasar menunjukkan bahwa masih rendahnya angka partisipasi mereka di bidang pendidikan, khususnya dalam ketuntasan wajib belajar 9 tahun. Mayoritas perekonomian keluarga nelayan di Kecamatan Puger juga masih tergolong rendah, hal ini tergambar dari masih banyaknya keluarga nelayan di Desa Puger Kulon yang kurang sejahtera.

Pembahasan di atas menunjukan bahwa pendidikan anak di Kecamatan Puger Desa Puger Kulon Kabupaten Jember masih tergolong rendah. Penulis berasumsi bahwa rendahnya tingkat pendidikan anak berkaitan dengan kondisi sosial ekonomi nelayan di Kecamatan Puger khususnya pada Desa Puger Kulon. Melihat dari realita yang ada maka penulis tertarik untuk meneliti lebih dalam tentang bagaimana pengaruh kondisi sosial dan ekonomi terhadap minat anak keluarga nelayan untuk melanjutkan pendidikan ke perguruan tinggi di pesisir pantai selatan khususnya di Kecamatan Puger Desa Puger Kulon dengan mengambil judul mengkaji pengaruh aspek kondisi sosial dan ekonomi terhadap minat anak keluarga nelayan untuk melanjutkan pendidikan ke perguruan tinggi.

\section{Kondisi Sosial Orang Tua/Keluarga}

Kondisi sosial merupakan keadaan yang berkenaan dengan kemasyarakatan yang selalu mengalami perubahan melalui proses sosial. Proses sosial dapat diartikan sebagai proses hubungan antara manusia satu dengan manusia yang lainnya, seperti individu dengan individu, individu dengan kelompok dan kelompok dengan kelompok berdasarkan potensi dan kemampuan yang dimiliki masing-masing. Proses sosial ini berlangsung terus menerus atau bahkan dapat membentuk lingkaran yang tidak ada ujungnya. Proses sosial merupakan bentuk lain dari interaksi sosial. Menurut Soekanto (2007:61) interaksi sosial merupakan hubungan-hubungan sosial yang dinamis yang menyangkut hubungan-hubungan antara rang perorangan, antara kelompokkelompok manusia, maupun antara orang perorangan dengan kelompok manusia. Sedangkan menurut Abdulsyani (2007:152) interaksi sosial diartikan sebagai hubunganhubungan timbal balik yang dinamis yang menyangkut hubungan antara orang-orang secara perseorangan, antara kelompok manusia maupun antara orang dengan kelompok-kelompok manusia. Di dalam keluarga interaksi sosial didasarkan atas rasa kasih sayang antara anggota keluarga yang diwujudkan dengan perhatian, kepedulian terhadap sesama anggota keluarga, saling membantu dan bekerjasama.

Kondisi sosial keluarga dapat dilihat dari interaksi sosial yang terjadi dalam keluarga itu yakni hubungan diantara anggota keluarga dan interaksi anggota keluarga dengan masyarakat di lingkungannya. Interaksi sosial dalam keluarga biasanya didasarkan atas rasa kasih sayang dan tanggung jawab yang diwujudkan dengan perhatian, bekerjasama, saling membantu dan saling peduli antara sesama anggota keluarga. Bentuk interaksi orang tua terhadap anak dapat terwujud dengan kepedulian orang tua terhadap masa depan pendidikan anaknya. Selain bentuk interaksi orang tua terhadap anak, tingkat pendidikan orang tua juga akan mempengaruhi masa depan pendidikan anaknya, karena semakin tinggi tingkat 
pendidikan orang tua maka akan semakin besar kepedulian orang tua terhadap masa depan pendidikan anaknya.

\section{Kondisi Ekonomi Orang Tua/Keluarga}

Menurut Sukirno (2008) ilmu ekonomi adalah suatu studi mengenai individu-individu dan masyarakat membuat pilihan, dengan atau tanpa penggunaan uang, dengan menggunakan sumber-sumber daya yang terbatas tetapi dapat digunakan dalam berbagai cara untuk menghasilkan berbagai jenis barang dan jasa dan mendistribusikannya untuk kebutuhan konsumsi, sekarang dan di masa datang, kepada berbagai individu dan golongan masyarakat. Kondisi ekonomi orang tua adalah suatu keadaan yang dapat dilihat manusia, mengenai keadaan dan kemampuan orang tua dalam memenuhi kebutuhannya.

Dari pengertian di atas dapat ditarik kesimpulan bahwa permasalahan ekonomi yang dihadapi orang tua/keluarga yang utama adalah usaha orang tua/keluarga untuk dapat memenuhi kebutuhannya, baik kebutuhan jasmani maupun kebutuhan rohani. Kondisi ekonomi orang tua dalam kehidupan sehari-hari dihadapkan pada dua hal yang saling berhubungan yakni pendapatan atau penghasilan orang tua yang sifatnya terbatas dan pengeluaran untuk pembiayaan atau pemenuhan kebutuhan keluarga yang sifatnya tidak terbatas.

\section{Minat Anak Melanjutkan Pendidikan ke Perguruan Tinggi}

Minat adalah kecenderungan dari dalam individu untuk tertarik pada sesuatu obyek atau menyenangi sesuatu obyek semakin kuat atau dekat hubungan tersebut maka semakin besar minatnya. Soedomo berpendapat (2008: 133), pendidikan tinggi merupakan kelanjutan pendidikan menengah dan diselenggarakan untuk menyiapkan peserta didik menjadi anggota masyarakat yang memiliki kemampuan akademik maupun kemampuan professional yang dapat menerapkan, mengembangkan dan menciptakan ilmu pengetahuan dan teknologi.
Perguruan tinggi adalah satuan yang menyelenggarakan pendidikan tinggi, satuan pendidikan yang menyelenggarakan pendidikan tinggi disebut perguruan tinggi dan dapat berbentuk universitas, institut, sekolah tinggi, politeknik dan akademi. Menurut Fuad Ihsan (2003: 23), pendidikan tinggi diartikan sebagai pendidikan yang mempersiapkan peserta didik untuk menjadi anggota masyarakat yang memiliki tingkat kemampuan tinggi yang bersifat akademik dan atau profesional sehingga dapat menerapkan, mengembangkan dan/atau menciptakan ilmu pengetahuan, teknologi dan seni dalam rangka pembangunan nasional dan meningkatkan kesejahteraan manusia.

Dalam penelitian ini, yang dimaksud dengan minat anak melanjutkan studi ke Perguruan Tinggi adalah kecenderungan yang mengandung unsur perasaan senang, keinginan, perhatian, ketertarikan, kebutuhan, harapan, dorongan dan kemauan untuk melanjutkan pendidikan ke jenjang yang lebih tinggi setelah lulus sekolah menengah, yaitu Perguruan Tinggi

\section{METODE PENELITIAN}

\section{Lokasi Penelitian}

Lokasi penelitian ini adalah di Kecamatan Puger, Desa Puger Kulon. Alasan pemilihan lokasi adalah karena lokasi tersebut mayoritas adalah keluarga nelayan. Data sampel yang diambil dalam penelitian ini berjumlah 120 responden, yaitu anak nelayan khusunya yang sudah masuk kejenjang pendidikan SMA/SMK kelas XII.

\section{Variabel Yang Diukur}

Penelitian ini memiliki dua macam variabel yaitu variabel independen dan variabel dependen.

a. Variabel independen (X), terdiri dari kondisi sosial $\left(\mathrm{X}_{1}\right)$ dan kondisi ekonomi $\left(\mathrm{X}_{2}\right)$. Variabel tersebut diukur menggunakan skala likert.

b. Variabel Terikat (Dependent Variabel) adalah minat anak melanjutkan ke perguruan tinggi. Variabel tersebut diukur menggunakan skala likert, 
dengan kriteria Sangat Setuju (SS) nilainya 5, Setuju (S) nilainya 4, Cukup (C) nilainya 3, tidak Setuju (TS) nilainya 2 dan Sangat Tidak Setuju (STS) nilainya 1.

\section{Model Yang Digunakan}

Model penelitian yang digunakan adalah penelitian Kuantitatif. Penelitian kuantitatif adalah penelitian yang dapat memberikan gambaran tentang suatu keadaan. Informasi yang diperoleh memberikan keterangan, gambaran atau fakta mengenai suatu persoalan dalam bentuk katagori huruf atau bilangan.

\section{Rancangan Penelitian}

Rancangan penelitian ini diklasifikasikan sebagai penelitian explanatory research yaitu penelitian untuk menguji hubungan atau pengaruh antar variabel yang dihipotesiskan. Pada penelitian ini jelas ada hipotesis yang akan diuji kebenarannya. Hipotesis itu sendiri menggambarkan hubungan antar dua variabel atau lebih variabel, untuk mengetahui apakah suatu variabel berasosiasi ataukah tidak dengan variabel lainnya; atau apakah suatu variabel disebabkan/dipengaruhi ataukah tidak oleh variabel lainnya (Faisal, 2007:21).

\section{Teknik Pengumpulan Data}

Metode pengumpulan data yang digunakan adalah:

a. Kuisioner, adalah sejumlah pertanyaan yang digunakan untuk memperoleh informasi mengenai minat anak dari responden, dan responden diminta mengisi daftar pertanyaan tersebut.

b. Dokumentasi, yaitu teknik pengumpulan data yang dilakukan dengan cara mendokumentasikan hasil penelitian yang diperoleh dari objek peneliti.

\section{Teknik Analisa Data}

\section{Uji Instrumen Penelitian}

\section{Uji Validitas dan Reliabilitas}

Untuk mengetahui apakah data yang diperoleh dapat mengukur apa yang kita harapkan, dan dapat mengungkapkan data variabel yang diteliti secara tepat, maka instrument penelitian ini perlu diuji terlebih dahulu, untuk itu perlu dilakukan uji validitas. Uji validitas instrumen penelitian dilakukan dengan menggunakan rumus korelasi product moment pearson. Item atau butir pertanyaan dapat dinyatakan valid jika nilai $r$ (koefisien korelasi antara skor butir pertanyaan dengan total skor) $>r_{\text {tabel }}$.

Sedangkan untuk uji Reliabilitas menunjukan pada suatu pengertian bahwa suatu instrument cukup dipercaya untuk digunakan sebagai alat pengumpul data karena instrument tersebut sudah baik. Uji reabilitas menggunakan cronbach's alpha, suatu instrument dikatakan reliable apabila cronbach alpha lebih besar dari 0,60

\section{Uji Asumsi Klasik}

a. Uji Normalitas Data

Data yang baik dan layak digunakan dalam penelitian adalah data yang memiliki distribusi normal. Model regresi yang baik adalah berdistribusi normal atau mendekati normal. Suatu data dikatakan mengikuti distribusi normal dilihat dari penyebaran data pada sumbu diagonal dari grafik (Ghozali,

b. Uji Multikolineritas

Mengukur multikolinieritas dilihat dari nilai tolerance atau VIF Variance Inflation Factor) dari masing-masing variabel. Apabila nilai tolerance TOL > 0,1 atau VIF > 10 maka terjadi multikolinieritas sehingga variabel tersebut harus dibuang atau sebaliknya (Yarnest, 2004 : 68).

c. Uji Heteroskedastisitas

Metode formal untuk mendeteksi keberadaan heteroskedastisitas adalah dengan menggunakan Glejser Test. Jika variabel independen signifikan secara statistik > 5\% memengaruhi variabel dependen, maka ada indikasi terjadi Heterokedastisitas.

\section{Analisis Data (Analisis Regresi Linier Berganda)}

Digunakan Model Regresi Linier Berganda. Adapun rumus dari regresi linier berganda adalah: 
$Y=b_{0}+b_{1} X_{1}+b_{2} X_{2}+b_{3} X_{3}+e i$

Dimana :

$\mathrm{Y} \quad=$ Minat anak

$\mathrm{b}_{\mathrm{O}} \quad=$ Konstanta

$\mathrm{b}_{1}, \mathrm{~b}_{2}, \quad=$ Koefisien tiap-tiap variabel

$\mathrm{X}_{1} \quad=$ Kondisi sosial

$\mathrm{X}_{2} \quad=$ kondisi ekonomi

Analisis Determinasi Berganda $\left(\mathbf{R}^{2}\right)$

Dalam penelitian ini terdiri dari beberapa variabel, maka digunakan koefisien determinasi $\left(\mathrm{R}^{2}\right)$ dapat digunakan untuk mengetahui beberapa persen besarnya sumbangan atau kontribusi dari variabel bebas $(\mathrm{X})$ terhadap variabel terikat $(\mathrm{Y})$.

\section{Uji Hipotesis}

Uji t $\left(\mathbf{t}_{\text {tes }}\right)$

Uji $\mathrm{t}$ digunakan untuk menguji apakah terdapat pengaruh secara parsial antara masing-masing variabel independen terhadap variabel dependen. Dasar pengambilan keputusan adalah dengan membandingkan antara nilai probabilitas (p)

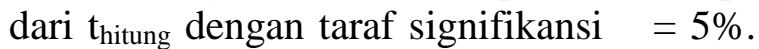
Untuk menentukan apakah hipotesis nol diterima atau ditolak dibuat ketentuan sebagai berikut:

a. $\mathrm{t}_{\text {tabel }} \leq \mathrm{t}_{\text {hitung }} \leq \mathrm{t}_{\text {tabel }}$ berarti Ho diterima dan Ha ditolak, sehingga secara parsial tidak terdapat pengaruh yang signifikan antara variabel independent (X) terhadap variabel dependent $(\mathrm{Y})$.

b. $t_{\text {hitung }}>t_{\text {tabel }}$ berarti Ho ditolak dan $\mathrm{Ha}$ diterima, sehingga secara parsial terdapat pengaruh yang signifikan antara variabel independent (X) terhadap variabel dependent $(\mathrm{Y})$.

\section{Uji F ( Fest $_{\text {te }}$}

Uji $F\left(F_{\text {test }}\right)$ adalah metode dalam pengujian hipotesa dimana kegunaannya dari Uji $F$ ini adalah untuk mengetahui pengaruh secara simultan atau bersamasama variabel independen terhadap variabel dependen. Dasar pengambilan keputusan adalah membandingkan antara nilai $F_{\text {hitung }}$ dan $\mathrm{F}_{\text {tabel}}$, dengan tingkat signifikansi yang diharapkan adalah $\alpha=5 \%$. Untuk menentukan apakah hipotesis nol diterima atau ditolak dibuat ketentuan sebagai berikut:

a. $\quad \mathrm{F}_{\text {hitung }}<\mathrm{F}_{\text {tabel }}$ berarti Ho diterima dan $\mathrm{Ha}$ ditolak, artinya ke dua variabel $\mathrm{X}$ tidak berpengaruh secara simultan terhadap minat $(\mathrm{Y})$.

b. $\mathrm{F}_{\text {hitung }}>\mathrm{F}_{\text {tabel }}$ berarti Ho ditolak dan $\mathrm{Ha}$ diterima, artinya ke dua variabel $\mathrm{X}$ berpengaruh secara simultan terhadap minat $(\mathrm{Y})$.

\section{HASIL DAN PEMBAHASAN}

Setelah dinyatakan valid dan reliabel, maka dilanjutkan dengan uji asumsi klasik dan kemudian analisis regresi linier berganda. Analisis Regresi linier berganda dilakukan untuk menganalisis pengaruh aspek kondisi sosial dan kondisi ekonomi orang tua terhadap minat anak melanjutkan kejenjang perguruan tinggi. Hasil Uji Regresi Linier Berganda dapat dilihat pada Tabel 1.

Tabel 1. Hasil Ringkasan Analisis Regresi Linier Berganda

\begin{tabular}{lccc}
\hline \multicolumn{1}{c}{ Variabel } & $\begin{array}{c}\text { Unstand. } \\
\text { Coeffici } \\
\text { ents }(\beta)\end{array}$ & $\mathrm{t}_{\text {hitung }}$ & Sig \\
& 20,154 & & \\
\hline (Constant) & 0,213 & 2,71 & 0,000 \\
Kondisi Sosial & 0,131 & 4 & 0,000 \\
Kondisi & & 3,30 & \\
Ekonomi & & 4 & \\
& & & \\
\hline
\end{tabular}

R Square $=$

0.125

$\mathrm{F}_{\text {hitung }}=8,342$

Sign. F $=0,000$

Sumber : Data diolah. 2017.

Model regresi berdasarkan hasil analisis di atas adalah:

$Y=20,154+0,213 X_{1}+0,131 X_{2}$

\section{Hasil Uji t}

Uji $t$ digunakan untuk menguji apakah terdapat pengaruh secara parsial antara masing-masing variabel independen terhadap variabel dependen, serta untuk mengetahui variabel manakah yang paling 
dominan terhadap minat anak keluarga nelayan untuk melanjutkan ke perguruan tinggi. Dasar pengambilan keputusan adalah dengan membandingkan antara nilai probabilitas (p) dari $\mathrm{t}_{\text {hitung }}$ dengan taraf signifikansi $\alpha=5 \%$ atau confidence interval $95 \%$ dan dengan degree of freedom atau df (n-k) dimana $\mathrm{k}$ merupakan jumlah variabel independen atau variabel regresor. Serta membandingkan coefficients Beta nya.

Hasil pengujian uji t selengkapnya dapat dilihat pada tabel 2 .

Tabel 2 Hasil Uji t masing-masing variabel

\begin{tabular}{lcccc}
\hline Variabel & $\mathrm{B}$ & $\mathrm{T}_{\text {hitung }}$ & $\mathrm{T}_{\text {tabel }}$ & $\mathrm{Sig}$ \\
\hline Constant & 20,154 & 9,618 & 1,980 & 0,000 \\
\cline { 1 - 2 } $\begin{array}{l}\text { Kondisi } \\
\begin{array}{l}\text { Sosial } \\
\text { Kondisi } \\
\text { Ekonomi }\end{array}\end{array}$ & 0,213 & 2,174 & & 0,008 \\
\cline { 1 - 2 } & & 3,304 & & 0,001 \\
\hline
\end{tabular}

Sumber : Data diolah. 2017

Berdasarkan tabel 2 maka dapat diketahui bahwa semua variabel kondisi sosial dan kondisi ekonomi berpengaruh signifikan secara parsial terhadap minat anak melanjutkan kejenjang perguruan tinggi. Masing- masing variabel dapat dijelaskan sebagai berikut:

1) Berdasarkan hasil analisis Coefficients data regresi linear berganda pada variabel $\mathrm{X}_{1}$ kondisi sosial terhadap minat, maka didapat Nilai $t_{\text {hitung dari }}$ variabel Kondisi sosial $\left(\mathrm{X}_{1}\right)$ lebih besar dari $t_{\text {tabel }}(2,714>1,980)$, dan taraf sig $0,00<0,05$ hal ini menunjukkan bahwa $\mathrm{H}_{\mathrm{o}}$ ditolak, artinya secara parsial terdapat pengaruh yang signifikan antara variabel independent kondisi sosial $\left(\mathrm{X}_{1}\right)$ terhadap variabel dependent minat $(\mathrm{Y})$.

2) Berdasarkan hasil analisis Coefficients data regresi linear berganda pada variabel $\mathrm{X}_{2}$ kondisi ekonomi terhadap minat, maka didapat Nilai $t_{\text {hitung }}$ dari variabel Kondisi ekonomi $\left(\mathrm{X}_{2}\right)$ lebih besar dari $t_{\text {tabel }}(3,304>1,980)$, dan taraf sig $0,00<0,05$ hal ini menunjukkan bahwa $\mathrm{H}_{\mathrm{o}}$ ditolak, artinya secara parsial terdapat pengaruh yang signifikan antara variabel independent kondisi ekonomi
$\left(\mathrm{X}_{2}\right)$ terhadap variabel dependent minat (Y).

3) Berdasarkan hasil analisis Coefficients data regresi linear berganda menunjukkan bahwa nilai koefisien Beta pada aspek kondisi sosial lebih tinggi daripada nilai koefisien Beta dari aspek kondisi ekonomi yaitu sebesar 0,213 > 0,131 . Hal ini memberikan kesimpulan bahwa aspek kondisi sosial lebih dominan mempengaruhi minat anak nelayan untuk melanjutkan Pendidikan Ke Perguruan Tinggi.

\section{Hasil Uji F}

Uji $F\left(F_{\text {test }}\right)$ adalah metode dalam pengujian hipotesa dimana kegunaannya dari Uji $F$ ini adalah untuk mengetahui pengaruh secara simultan atau bersamasama variabel independen terhadap variabel dependen. Dasar pengambilan keputusan adalah membandingkan antara nilai $F_{\text {hitung }}$ dan $\mathrm{F}_{\text {tabel }}$, dengan tingkat signifikansi yang diharapkan adalah $\alpha=5 \%$ atau confidence interval $95 \%$ dan dengan degree of freedom atau df (n-k) dimana $\mathrm{k}$ merupakan jumlah variabel independen atau variabel regresor.

Berdasarkan hasil uji analisis ANOVA menunjukkan bahwa hasil secara simultan uji $\mathrm{F}$ yaitu diperoleh $\mathrm{F}_{\text {hitung }} 8,342>\mathrm{F}_{\text {tabel }}$ 3,07 , dan hasil taraf sig $0,000<0,05$. Hal ini dapat disimpulkan bahwa $\mathrm{H}_{\mathrm{o}}$ ditolak dan menerima $\mathrm{H}_{\mathrm{a}}$ yang artinya terdapat pengaruh signifikan secara simultan variabel kondisi sosial $\left(\mathrm{X}_{1}\right)$ dan kondisi ekonomi $\left(\mathrm{X}_{2}\right)$ terhadapa minat anak keluarga nelayan untuk melanjutkan pendidikan ke perguruan tinggi.

\section{Hasil Uji Determinasi}

Hasil analisis Rsquare menunjukkan bahwa nilainya sebesar 0,125 . Hal ini mengindikasikan bahwa minat ke perguruan tinggi dipengaruhi oleh kondisi sosial dan ekonomi seperti tingkat pendidikan, lingkungan keluarga pendapatan keluarga dan beban keluarga sebesar $12,5 \%$. Sisanya sebesar $87,5 \%$ dipengaruhi oleh variabel lainnya.

Pada bagian ini akan dibahas analisis terhadap hasil penelitian yang telah dibahas 
pada sebelumnya. Hasil analisis penelitian ini menunjukkan secara garis besar hasil penelitian menunjukkan bahwa hipotesis yang diajukan dapat diterima. Hipotesis yang dimaksud adalah Hipotesis yang diajukan adalah ada pengaruh antara kondisi sosial dan kondisi ekonomi terhadap minat anak keluarga nelayan untuk melanjutkan pendidikan ke perguruan tinggi.

\section{a. Pengaruh kondisi sosial terhadap minat anak keluarga nelayan untuk melanjutkan pendidikan ke perguruan tinggi}

Pada hasil analisis Coefficients data regresi linear berganda pada variabel $\mathrm{X}_{1}$ kondisi sosial terhadap minat, maka didapat Nilai $t_{\text {hitung }}$ dari variabel Kondisi sosial $\left(\mathrm{X}_{1}\right)$ lebih besar dari $t_{\text {tabel }}(2,714>1,980)$, dan taraf sig $0,00<0,05$ hal ini menunjukkan bahwa $\mathrm{H}_{\mathrm{o}}$ ditolak, artinya secara parsial terdapat pengaruh yang signifikan antara variabel independent kondisi sosial $\left(\mathrm{X}_{1}\right)$ terhadap variabel dependent minat (Y). Berdasarkan hasil penelitian ini bahwa ada pengaruh secara parsial kondisi sosial terhadap minat anak nelayan untuk melanjutkan pendidikan ke perguruan tinggi di Kecamatan Puger Desa Puger Kulon Kabupaten Jember. Hal ini juga sesuai dengan hasil wawancara yang dilakukan bahwa, dari kondisi sosial keluarga anak nelayan dengan berbagai macam-macam latar belakang pendidikan orang tua anak yang masih ada yang pendidikannya rendah tapi mayoritas pendidikan orang tua memiliki pendidikan tinggi dan kondisi lingkungan yang mayoritas maju. Sehingga dapat dikatakan kondisi sosial orang tua sangat mendukung anak tersebut untuk melanjutkan ke perguruan tinggi. Penelitian ini juga sesuai dengan hasil penelitian yang dilakukan oleh Khoerunisa (2014) yang di dalam jurnalnya terdapat pengaruh positif motivasi, prestasi belajar status sosial ekonomi dan lingkungan sekolah terhadap minat melanjutkan pendidikan keperguruan tinggi,

\section{b. Pengaruh kondisi ekonomi terhadap minat anak keluarga nelayan untuk}

\section{melanjutkan pendidikan ke perguruan tinggi}

Pada hasil analisis Coefficients data regresi linear berganda pada variabel $\mathrm{X}_{2}$ kondisi ekonomi terhadap minat, maka didapat Nilai $t_{\text {hitung dari variabel Kondisi }}$ ekonomi $\left(\mathrm{X}_{2}\right)$ lebih besar dari $\mathrm{t}_{\text {tabel }}(3,304>$ 1,980), dan taraf sig $0,00<0,05$ hal ini menunjukkan bahwa $\mathrm{H}_{\mathrm{o}}$ ditolak, artinya secara parsial terdapat pengaruh yang signifikan antara variabel independent kondisi ekonomi $\left(\mathrm{X}_{2}\right)$ terhadap variabel dependent minat (Y). Berdasarkan hasil penelitian ini bahwa ada pengaruh secara parsial kondisi ekonomi terhadap minat anak nelayan untuk melanjutkan pendidikan ke perguruan tinggi di Kecamatan Puger Desa Puger Kulon Kabupaten Jember. Hal ini juga sesuai dengan hasil wawancara yang dilakukan bahwa, dari kondisi Orang tua dengan penghasilan yang tinggi akan mampu memenuhi berbagai macam sarana dan prasarana yang menunjang kegiatan belajar anak. Semakin tinggi pendidikan orang tua semakin berkualitas perhatian yang diberikan kepada anaknya, Dengan demikian anak yang hidup dalam lingkungan keluarga dengan penghasilan orang tua yang tinggi dia dengan mudah mendapatkan sarana dan prasarana dalam belajar, sehingga kegiatan belajar akan maksimal. Penelitian ini juga didukung dengan hasil penelitian yang dilakukan oleh Khoerunisa (2014) yang di dalam jurnalnya terdapat pengaruh positif motivasi, prestasi belajar status sosial ekonomi dan lingkungan sekolah terhadap minat melanjutkan pendidikan keperguruan tinggi,

\section{c. Pengaruh kondisi sosial dan kondisi ekonomi terhadap minat anak nelayan untuk melanjutkan pendidikan ke perguruan tinggi \\ Pada hasil uji analisis ANOVA} menunjukkan bahwa hasil secara simultan uji $\mathrm{F}$ yaitu diperoleh $\mathrm{F}_{\text {hitung }} 8,342>\mathrm{F}_{\text {tabel }}$ 3,07 , dan hasil taraf sig $0,000<0,05$. Hal ini dapat disimpulkan bahwa $\mathrm{H}_{\mathrm{o}}$ ditolak dan menerima $\mathrm{H}_{\mathrm{a}}$ yang artinya terdapat pengaruh signifikan secara simultan variabel kondisi sosial $\left(\mathrm{X}_{1}\right)$ dan kondisi ekonomi $\left(\mathrm{X}_{2}\right)$ 
terhadap minat anak keluarga nelayan untuk melanjutkan pendidikan ke perguruan tinggi. Berdasarkan hasil penelitian ini bahwa ada pengaruh secara simultan aspek kondisi sosial dan ekonomi terhadap minat anak keluarga nelayan untuk melanjutkan Pendidikan Ke Perguruan Tinggi Di Kecamatan Puger Desa Puger Kulon Kabupaten Jember. Hal ini juga sesuai dengan hasil wawancara yang dilakukan bahwa, minat pada anak nelayan untuk melanjutkan pendidikan ke perguruan tinggi dapat timbul dan dipengaruhi oleh beberapa faktor. Shaleh dan Wahab (2004:263) menjelaskan beberapa faktor yang dapat menimbulkan minat anak terhadap sesuatu dapat dikelompokkan menjadi dua yaitu yang bersumber dari dalam diri anak dan dari luar anak yang bersangkutan. Beberapa faktor yang berasal dari dalam diri anak yaitu bobot, umur, jenis kelamin, pengalaman, perasaan mampu,dan kepribadian. Faktor-faktor yang berasal dari luar diri anak mencakup lingkungan keluarga, lingkungan sekolah, dan lingkungan masyarakat. Dengan keadaan seperti itu sangat mendukung anak melanjutkan kejenjang perguruan tinggi. Penelitian ini juga didukung dengan hasil penelitian yang dilakukan oleh Khoerunisa (2014) yang di dalam jurnalnya terdapat pengaruh positif motivasi, prestasi belajar status sosial ekonomi dan lingkungan sekolah terhadap minat melanjutkan pendidikan keperguruan tinggi.

\section{d. Pengaruh antara aspek kondisi sosial dan kondisi ekonomi terhadap minat anak melanjutkan ke perguruan tinggi}

Berdasarkan hasil analisis

Coefficients data regresi linear berganda menunjukkan bahwa nilai koefisien Beta pada aspek kondisi sosial lebih besar daripada nilai koefisien Beta dari aspek kondisi ekonomi yaitu sebesar 0,213 > 0,131 . Hal ini juga sesuai dengan hasil analisis deskriptif data aspek kondisi sosial dengan kondisi ekonomi, yang menunjukkan nilai rata-ratanya lebih besar yaitu $24,03>22,31$. Dari hasil tersebut dapat disimpulkan bahwa aspek kondisi sosial lebih dominan mempengaruhi minat anak nelayan untuk melanjutkan Pendidikan Ke Perguruan Tinggi di Kecamatan Puger Desa Puger Kulon Kabupaten Jember. Sesuia dengan hasil wawancara yang sudah dilakukan oleh peneliti, memang dari aspek kondisi sosial pada masyarakat nelayan di desa Puger Kulon khususnya pada latar belakang tingkat pendidikannya cenderung menganggap pendidikan anak adalah hal yang sangat penting, meskipun rata-rata orang tua mereka lulusan SMA, sehingga minat mereka untuk memberikan pendidikan kepada anaknya sampai ke jenjang perguruan tinggi sangat tinggi. Serta dilihat dari kondisi lingkungan tempat tinggal meliputi lingkungan keluarga dan lingkungan masyarakat juga sangat mendukung, dikarenakan suasana lingkungan keluarga berkecukupan, tentram dan damai, sehingga kondisi tersebut sangat memberikan pengaruh terhadap minat anak untuk melanjutkan pendidikannya ke jenjang yang lebih tinggi.

\section{PENUTUP}

\section{Simpulan}

Berdasarkan hasil analisis data dan pembahasan, maka dapat diambil kesimpulan sebagai berikut:

1. Pada hasil analisis Coefficients data regresi linear berganda pada variabel $\mathrm{X}_{1}$ kondisi sosial terhadap minat, dilihat dari nilai $t_{\text {hitung }}>\mathrm{t}_{\text {tabel }}$ dan taraf sig 0,00 $<0,05$ hal ini menunjukkan bahwa ada pengaruh secara parsial kondisi sosial terhadap minat anak nelayan untuk melanjutkan pendidikan ke perguruan tinggi di Kecamatan Puger Desa Puger Kulon Kabupaten Jember. Dengan demikian hipotesis pertama yang menyatakan bahwa variabel kondisi sosial terhadap minat anak nelayan untuk melanjutkan pendidikan ke perguruan tinggi, diterima.

2. Pada hasil analisis Coefficients data regresi linear berganda pada variabel $\mathrm{X}_{2}$ kondisi ekonomi terhadap minat, dilihat dari nilai $t_{\text {hitung }}>t_{\text {tabel }}$ dan taraf sig 0,00 $<0,05$ hal ini menunjukkan bahwa ada 
pengaruh secara parsial kondisi ekonomi terhadap minat anak nelayan untuk melanjutkan pendidikan ke perguruan tinggi di Kecamatan Puger Desa Puger Kulon Kabupaten Jember. Dengan demikian hipotesis kedua yang menyatakan bahwa variabel kondisi ekonomi terhadap minat anak nelayan untuk melanjutkan pendidikan ke perguruan tinggi, diterima.

3. Pada hasil uji analisis ANOVA menunjukkan bahwa hasil secara simultan uji $\mathrm{F}$ yaitu diperoleh $\mathrm{F}_{\text {hitung }}>$ $F_{\text {tabel }}$ dan hasil taraf sig $0,000<0,05$, maka dapat disimpulkan bahwa ada pengaruh secara simultan aspek kondisi sosial dan ekonomi terhadap minat anak keluarga nelayan untuk melanjutkan Pendidikan Ke Perguruan Tinggi Di Kecamatan Puger Desa Puger Kulon Kabupaten Jember. Dengan demikian hipotesis ketiga yang menyatakan bahwa variabel kondisi sosial dan kondisi ekonomi terhadap minat anak nelayan untuk melanjutkan pendidikan ke perguruan tinggi, diterima.

4. Berdasarkan hasil analisis Coefficients data regresi linear berganda menunjukkan bahwa nilai koefisien Beta pada aspek kondisi sosial lebih besar daripada nilai koefisien Beta dari aspek kondisi ekonomi. Hal ini juga sesuai dengan hasil analisis deskriptif data aspek kondisi sosial lebih besar daripada nilai rata-rata kondisi ekonomi. Dari hasil tersebut dapat disimpulkan bahwa aspek kondisi sosial lebih dominan mempengaruhi minat anak nelayan untuk melanjutkan Pendidikan Ke Perguruan Tinggi di Kecamatan Puger Desa Puger Kulon Kabupaten Jember. Artinya hipotesis keempat yang menyatakan bahwa variabel manakah yang lebih dominan mempengaruhi minat anak nelayan untuk melanjutkan Pendidikan Ke Perguruan Tinggi Di Kecamatan Puger Desa Puger Kulon Kabupaten Jember, dapat diterima.

\section{Saran}

Berdasarkan hasil analisis dan kesimpulan penelitian ini, maka dapat saran yang perlu dijelaskan yaitu berkaitan dengan Indikator yang mempengaruhi minat anak untuk melanjutkan pendidikan ke perguruan tinggi sangat banyak, salah satunya faktor kondisi sosial dan ekonomi orang tua. Karena 2 faktor tersebut merupkan unsur yang sangat penting bagi anak atau siswa untuk ingin melanjutkan jenjang pendidikannya yang lebih tinggi. Misalnya saja kondisi ekonomi yang memang di daerah Puger Kulon rata-rata mampu. Akan tetapi kemampuan tersebut masih lebih digunakan untuk keperluan yang lainnya, artinya anggapan orang tua anak tersebut untuk menginginkan anankya melanjutkan keperguruan tinggi masih lemah. Untuk itu perlu bagi orang tua diharapkan dapat mengoptimalkan pendapatannya dengan memperhatikan fasilitas dan sarana prasarana anak, begitu juga dengan perhatian orang tua yang memiliki peran besar untuk lebih memperhatikan anaknya dalam masalah menuntut ilmu dan meningkatkan pengetahuannya khususnya dalam mencari wawasan pengalaman didunia pendidikan, sehingga secara tidak langsung minat anak untuk melanjutkan pendidikannya kejenjang perguruan tinggi lebih tertarik untuk mencapai keinginanya.

\section{DAFTAR PUSTAKA}

Abdulsyani.2007. Sosiologi, Skematika, Teori, Dan Terapan. Jakarta: PT.Bumi Aksara.

Ajake, Uchenna Egodi. 2013. "Family Socio-Economic Status and Delinquency among Senior Secondary School Students in Calabar South, Cross River State, Nigeria". Dalam American International Journal of Contemporary Research, Volume 3 No. 4. Nigeria: University of Calabar

A.M. Sardiman. 2011. Interaksi dan Motivasi Belajar Mengajar. PT. Rajagrafindo: Jakarta. 
Depdiknas. 2003. Undang-Undang No.20

Tahun 2003 Tentang Sistem Pendidikan Nasional. Jakarta: Depdiknas.

Djamarah, Syiful Bahri. 2011. Psikologi Belajar. Jakarta: Rineka Cipta.

Djaali. 2008. Psikologi Pendidikan. PT. Bumi Aksara. Jakarta. Slameto (2010: 180).

Faisal, Sanapiah. 2007. Format - Format Penelitian Sosial. Jakarta: Raja Grafindo Persada.

Gerungan. 2006. Psikologi Sosial. Bandung: PT. Refika Aditama.

Ghozali, Imam. (2011). Aplikasi Analisis Multivariate Dengan Program IBM SPSS 19 (edisi kelima). Semarang: Universitas Diponegoro.

Khairani, Makmun. 2013. Psikologi Belajar. Yogyakarta: Aswaja Pressindo
Muhibbin Syah. 2011. Psikologi Belajar. Jakarta: PT Raja Grafindo Persada.

Ninuk Indriyanti. 2013. Faktor-Faktor yang Memengaruhi Minat Melanjutkan Pendidikan ke Perguruan Tinggi pada Anak Kelas XII Akuntansi SMK Negeri 6 Surakarta tahun 2013. Mei, 2013. Dalam Jupe UNS, Vol. 1, No. 2, Hal 1 s/d 10

Soedomo, Hadi. (2008). Pendidikan (suatu pengantar). Surakarta: Lembaga Pengembangan Pendidikan (LPP) UNS dan UPT Penerbitan dan Percetakan UNS (UNS Press).

Sukirno Sadono. 2008. Mikro Ekonomi Teori Pengantar. Jakarta. P.T Raja Grafindo Persada

Sumardi, Mulyanto dan Hans-Dieter Evers, ed. 1982. Kemiskinan dan Kebutuhan Pokok. Jakarta: CV.Rajawali 